\title{
Curriculum System Construction of Data Science and Big Data Technology under New Engineering Education Background
}

\author{
Le Wei*, Qiuyun Zhao \\ School of Software Engineering, Chengdu University of Information Technology, Chengdu 610225, China \\ *Corresponding author. Email: weile@cuit.edu.cn
}

\begin{abstract}
In order to meet the growing demand for big data talents, colleges and universities have set up data science and big data technology majors. Taking the construction of data science and big data technology specialty in Chengdu University of Information Technology as an example, it is introduced that how to establish a scientific curriculum system to achieve the training goal of application-oriented big data talents in local universities under the new engineering education background. The content and connotation of general education courses, basic courses and professional courses are expounded. The role of big data engineering courses is emphasized in talent training. Preliminary practice shows that the setting of the curriculum system fully considers the needs of the industry, its own positioning and the requirements of engineering education. It has a positive reference for the construction of data science and big data technology majors in related domestic universities.
\end{abstract}

Keywords: Curriculum system, big data, new engineering education, engineering education, training goal

\section{INTRODUCTION}

With the continuous progress of information technology, continuous innovation of the Internet, extensive use of social networks, widespread popularization of intelligent terminals, as well as the development of cloud computing and the Internet of things, the data scale increases exponentially [1], and the human society has entered the era of big data. At present, under the joint efforts of academic, scientific, industrial and other scientific and technological workers, the fusion and innovation of big data is undergoing a major revolution [2]. Big data has developed into an independent industrial form, covering production aggregation, organization and management, analysis and discovery, application services and other aspects of big data. It plays an important role in innovating industrial development mode, promoting agglomeration of related industries and driving regional economic development.

The healthy development of big data industry is inseparable from talents, but obviously, there is a huge gap between the supply and demand of big data talents. "2019 White Paper on The Development of China's Big Data Industry" points out that by the end of 2018 , there is a gap of 600,000 core big data talents nationwide, and it is expected that the gap will reach 2.3 million by 2025 [3]. The training of big data talents can be divided into degree training and vocational training, among which degree training is undertaken by colleges and universities, which are entrusted by the country and society. Since the Ministry of Education approved Peking University,
University of International Business and Economics and Central South University to offer data science and big data Technology majors in 2016, a total of 617 Chinese universities have offered data science and big data Technology majors by 2020 , with a rapid increase in the number, which shows that the country attaches great importance to the cultivation of big data talents.

Broadly speaking, big data talents are data scientists and data engineers [4]. To be specific, big data talents include not only core talents with professional skills such as algorithm design, programming and data analysis, but also compound talents with industry background and certain professional technology application of big data. New engineering education construction is a major action plan to continuously deepen engineering education reform on the basis of "Outstanding engineer education training Plan". It cultivates "new engineering education" talents with the consciousness of innovation and entrepreneurship, digital thinking and cross-border integration ability by constructing new engineering majors or major directions and transforming existing majors according to the framework of new engineering education paradigm [5]. In this context, the major of data science and Big data technology must implement new engineering education concepts in the training of big data talents, formulate a reasonable professional curriculum system, and cultivate complex big data talents with outstanding practical ability and technological innovation ability, so as to meet the social demand for big data talents.

After exploration in recent years, domestic colleges and universities have made remarkable achievements in big data talent training, such as constructing the curriculum system of data science and big data Technology, 
formulating the talent training mechanism integrating industry and education, improving the environment and conditions for talent training, and achieving the goal of talent training. However, in general, as a new major, the construction of data science and big data is still in the exploratory stage, and there are still some problems to be solved. Specifically, in the course system construction, the main reason is that the curriculum system construction is identical and the training support for ability is insufficient. Different types of colleges and universities do not fully consider the needs of local economic development and their own advantages, instead, they simply pile up courses of different disciplines or majors, and do not design the relationship between courses and training objectives in detail, which is not enough to support the cultivation of compound, applied and innovative big data professionals. Therefore, this article takes the professional construction of data science and big data technology in Chengdu University of Information Technology as an example. In the context of new engineering education, the article expounds how local colleges and universities combine the social demand for big data talents, give full play to their own advantages, build a characteristic course system, train "outstanding engineers" in the field of big data, and actively serve the local economic construction.

\section{DATA SCIENCE AND BIG DATA TECHNOLOGY PROFESSIONALS TRAINING OBJECTIVES}

At present, the demand positions for big data talents mainly include big data system research and development engineers, big data application development engineers, big data analysts and data visualization engineers. These positions require both technical experts and comprehensive talents, that is, big data talents need to master mathematics. Statistics, information technology and other professional knowledge, also need to have industry background and data management experience, at the same time have good team communication skills, ability to analyze and solve problems and a sense of social responsibility. In combination with social needs and their own characteristics, colleges and universities have formulated their own professional training objectives [68]. In general, the training objectives are mainly divided into big data engineering applied talents, big data technical skills talents and big data compound talents.

As an ordinary undergraduate college in Sichuan Province, Chengdu University of Information Technology is the national mid-western basic capacity-building engineering college and the first batch of pilot colleges for the "Excellent Engineer Education and Training Program". The University focuses on information science and atmospheric science and features interdisciplinary studies, forming three major clusters of atmospheric science, information technology and management economy, as well as characteristic disciplines such as software engineering, computer science and technology, network security, atmospheric science and statistics. After the approval of the major of Data Science and Big Data Technology applied by Chengdu University of Information Engineering in 2017, according to the development trend of information technology and the development goals of the industry, the school closely combines the practical needs of Sichuan Province to "build a "5+1" modern industrial system", combining the school's industry background, characteristic disciplines and explorations made in the field of engineering education, the goal of training talents in data science and big data with their own characteristics under the new engineering education background is proposed. details as follows:

Training to meet the needs of local economic construction and development of science and technology, with a solid mathematical foundation knowledge and innovation ability, familiar with based on the data analysis of the basic theory, method and technology, to be involved in big data service software system design and development work, data analysis, management of complex, high quality, practical data science and engineering and technical personnel.

(i) Can understand and abide by professional ethics and norms, have the sense of social responsibility;

(ii) Capable of conceiving, designing, implementing and implementing complex software products and information integration systems related to big data, such as data processing, data mining and data analysis, by using basic mathematical knowledge and relevant methods and technologies of software engineering;

(iii) Capable of designing and building software service systems according to the needs of specific industries in the context of big data; capable of solving specific industrial application problems by using the method of big data; engaged in data management and analysis in related fields, design and development of software products; capable of innovation; Good communication skills and project management skills;

(iv) Good foreign language communication skills, international vision and ability to adapt to career development through lifelong learning.

\section{CURRICULUM SYSTEM OF DATA SCIENCE AND BIG DATA TECHNOLOGY}

The major of Data Science and Big Data Technology involves computer science, mathematics, statistics and other disciplines, and is interdisciplinary. Therefore, the curriculum system of relevant universities at home and abroad is set around three disciplines. For example, the curriculum group of North American universities mainly includes basic mathematics courses, computer-related courses, data science-related courses and field-related courses [9], The curriculum groups of domestic colleges and universities mainly include: general courses, discipline basic courses, professional courses and comprehensive training courses. Of course, considering the different professional training objectives and the characteristics of 
different universities, there will be some differences in the specific curriculum.

Chengdu University of Information Technology majors in data science and big data technology are awarded engineering degrees by the School of Software. Based on the reality of local colleges and universities, combining the characteristics and advantages of the college, and giving full play to the experience of engineering education, the curriculum system is set up to theoretically focus on theoretically supporting the understanding and application of models in data science; in practice, focus on supporting the ability to process actual data; in application, the key support is the ability to use big data to solve specific industry application problems; and the curriculum system of "engineering supported by technology" has been formed. Specifically, the whole professional curriculum is divided into general education curriculum, subject foundation curriculum and professional curriculum, as shown in Table 1.

Table 1 Practice curriculum system of data science and big data technology

\begin{tabular}{|c|c|c|}
\hline \multicolumn{2}{|c|}{ Course Modules } & Course \\
\hline \multirow{20}{*}{$\begin{array}{l}\text { General Education } \\
\text { Courses(Compulsory } \\
\text { courses) }\end{array}$} & \multirow{5}{*}{$\begin{array}{l}\text { Ideological and Political } \\
\text { Courses }\end{array}$} & Thought Morals Tutelage and Legal Foundation \\
\hline & & Outline of Chinese Modern History \\
\hline & & Basic Principles of Marxism \\
\hline & & $\begin{array}{l}\text { Introduction to Mao Zedong Thought and Theory of } \\
\text { Socialism With Chinese Characteristics } 1,2\end{array}$ \\
\hline & & Situation \& Policy $1,2,3,4$ \\
\hline & $\begin{array}{l}\text { Foreign } \quad \text { Language } \\
\text { Courses }\end{array}$ & College English 1,2,3,4 \\
\hline & \multirow{6}{*}{$\begin{array}{l}\text { Mathematics and } \\
\text { Mathematics Courses }\end{array}$} & Advanced Mathematics 1,2 \\
\hline & & Linear Algebra \\
\hline & & Probability Theory and Mathematical Statistics \\
\hline & & College Physics \\
\hline & & Discrete Structure \\
\hline & & Theory and Application of Algorithm Analysis \\
\hline & \multirow{2}{*}{ Military Sports Courses } & Physical Education 1,2,3,4,5,6 \\
\hline & & Military Theory and Training \\
\hline & \multirow{6}{*}{$\begin{array}{l}\text { Innovation } \quad \text { and } \\
\text { Entrepreneurship } \\
\text { Courses }\end{array}$} & Life Planning and Pre-vocational Education \\
\hline & & Basic Education of Innovation and Entrepreneurship \\
\hline & & TRIZ Innovation Method \\
\hline & & SYB Innovation and Entrepreneurship Guidance \\
\hline & & Career Guidance \\
\hline & & Innovation, Invention and Practice of Intellectual Property \\
\hline \multirow{4}{*}{$\begin{array}{l}\text { Subject } \quad \text { Basic } \\
\text { Course(Compulsory } \\
\text { courses) }\end{array}$} & \multirow{4}{*}{$\begin{array}{l}\text { university-level subject } \\
\text { basic platform courses }\end{array}$} & C Language Programming \\
\hline & & Data Structure \\
\hline & & Object-Oriented Programming(Java) \\
\hline & & Database System Principles and Application \\
\hline
\end{tabular}




\begin{tabular}{|c|c|c|}
\hline \multicolumn{2}{|c|}{ Course Modules } & Course \\
\hline & & Principles of Operating System \\
\hline & & Principles of Computer Organization \\
\hline & & Computer Network \\
\hline & \multirow{6}{*}{$\begin{array}{l}\text { university-level } \\
\text { professional basic } \\
\text { platform courses }\end{array}$} & Engineering Practice 1 (Coding Training) \\
\hline & & Engineering Economics \\
\hline & & Engineering Practice 2 (Software Technology) \\
\hline & & Data Mining and Analysis \\
\hline & & Team Motivation and Communication \\
\hline & & Professional Practice of Software Engineering \\
\hline & \multirow{4}{*}{$\begin{array}{l}\text { professional basic } \\
\text { courses }\end{array}$} & Introduction to Data Science \\
\hline & & Introduction to Engineering \\
\hline & & Python Programming \\
\hline & & Fundamental of Information Retrieval \\
\hline \multirow{16}{*}{ Professional Courses } & \multirow{6}{*}{ Compulsory courses } & Engineering Practice on Big Data 1 \\
\hline & & Engineering Practice on Mathematical Methods \\
\hline & & Big Data Systems and Technologies \\
\hline & & Engineering Practice on Big Data 2 \\
\hline & & Graduation Practice \\
\hline & & Graduation Thesis/Design \\
\hline & & Textual Data Mining \\
\hline & Text data Science & Natural Language Processing \\
\hline & & Intelligent Text Analysis \\
\hline & & Image Processing Techniques \\
\hline & Image data Science & Image Analysis Methods \\
\hline & & Deep Learning Algorithms and Practice \\
\hline & & Web Application Programming(Java) \\
\hline & & Application Technology of Database(MySQL) \\
\hline & & Fundamental of Data Visualization \\
\hline & & Big Data Machine Learning \\
\hline
\end{tabular}




\subsection{General Education Courses}

General education courses are divided into ideological and political courses, foreign language courses, mathematics and mathematics courses, military sports courses and innovation and entrepreneurship courses. Ideological and political courses is the guiding ideology of the party and the spread of ruling idea in the universities and carry out, mainly includes the thought morals tutelage and legal foundation, the modern history of China, and basic principle of Marxism and Mao Zedong Thought and introduction to socialist theory with Chinese characteristics and the situation and policy, its purpose is to cultivate students to set up the scientific world outlook, the outlook on life and values. Foreign language courses mainly refer to college English, and its main purpose is to cultivate students' international perspectives so that they can communicate and communicate in a cross-cultural context. Military physical education courses include physical education and military theory and training. Its main purpose is to exercise students' physique, enhance college students' awareness of national defense, and improve the overall quality of college students. Mathematics basic courses mainly include advanced mathematics, linear algebra, probability theory and mathematical statistics, university physics, discrete structure and algorithm analysis theory and application. Its main purpose is to enable students to master the basic knowledge of big data related theory and engineering basic knowledge, cultivate Students' logical thinking ability and problem analysis ability are helpful for students to deal with complex big data engineering project problems. Innovation and entrepreneurship courses mainly include life planning and pre-employment education, the foundation of innovation and entrepreneurship education, TRIZ innovation method, SYB innovation and entrepreneurship guidance, employment guidance and innovation, invention and intellectual property practice, the purpose of which is to cultivate students' awareness of innovation and train students' Innovate thinking and stimulate students' entrepreneurial spirit.

\subsection{Subject Basic Course}

Subject basic courses are divided into university-level subject basic platform courses, university-level professional basic platform courses and professional basic courses. The courses of university-level discipline basic platform mainly include $\mathrm{C}$ language programming, data structure, Object-oriented programming (Java), database principle and application, operating system principle, computer composition principle and computer network, its purpose is to strengthen students' cognition of computer hardware and software, strengthen students' programming ability, enable students to master the professional basic knowledge required in the professional field, and skillfully use the professional basic knowledge. College-level professional basic platform courses mainly include engineering practice 1 (coding training), engineering economics, engineering practice 2 (software technology), data mining and analysis, team motivation and communication, and software engineering professional practice, Its purpose is to cultivate students' ability to design/develop solutions to solve complex engineering problems from the perspective of big data application development, so that students can understand engineering and society, engineering and environment and sustainable development, individuals and teams, professional standards for engineers, and interpersonal communication. The meaning of project management and its practical application in engineering projects. Professional basic courses mainly include introduction to Data science, Introduction to Engineering, Python programming and basic information retrieval. Their main purpose is to enable students to understand the basic knowledge of big data, master relevant research methods and tools, and lay a foundation for subsequent courses.

\subsection{Professional Courses}

Focusing on the technical system of big data (big data collection and preprocessing, big data storage and management, big data calculation mode and system, big data analysis and mining, big data visualization analysis and big data privacy and security), we designed data science and Big data technology professional courses. The compulsory courses of the whole major include big data Engineering Practice 1, mathematical method engineering practice, big data system and Technology, big data engineering Practice 2, graduation practice and graduation thesis (design); Elective course contains the text data scientific direction, scientific direction of micro image data as well as optional course, scientific direction of micro text data sets the text data mining, natural language processing and intelligent text analysis three courses, scientific direction of micro image data sets the image processing technology, image analysis and deep learning algorithms and practice three courses, of course including Web programming (Java), database application technology (MySQL), data visualization and data of machine learning. The purpose of professional courses is to enable students to master core professional knowledge and application technology, methods and tools of professional fields, basic methods of big data development and corresponding software development tools, and apply what they have learned to big data engineering projects to solve complex data science problems. Specifically speaking, it enables students to apply mathematics, natural science, engineering science, computer professional knowledge and big data technology to research and analyze complex data science and engineering problems; Using modern tools to design solutions to complex data science and engineering problems; In the process of solving problems, we should fully consider and practice the relationship between engineering and society, environment, sustainable development, individual and team, consciously abide by professional norms, effectively communicate with the 
outside world, conduct scientific management of projects, and cultivate the awareness of independent learning and lifelong learning.

The setting of the whole course system fully considers the development of big data technology, the realistic needs of the society and the university's own positioning, closely combines with the professional training objectives, highlights the engineering education concept in the context of new engineering education, and attaches importance to the integration of multiple disciplines and the cultivation of people. In particular, with the goal of cultivating applied talents as the orientation, the three-level practice system of course experiment, engineering practice, graduation practice and graduation design has been established. Through school-enterprise cooperation, close combination of production, learning and research, the laboratory, provincial and ministerial-level scientific research platform, practical training and internship base and innovation base, the engineering practice ability of students has been comprehensively improved.

\section{CONCLUSION}

The major of Data Science and Big Data Technology is a new engineering major set up to meet the social demand for big data talents. Its purpose is to cultivate high-level big data talents with big data thinking and analysis application technology. This article takes the practice and exploration of Chengdu University of Information Technology as an example, explains how to set up a big data curriculum system according to the needs of industrial development. The research is under the background of new engineering education, and combines colleges' and universities' own characteristics. By constructing a 'general education course + subject basic course + professional course' curriculum system, focusing on the cross-disciplinary integration, highlighting the application, engineering, innovation, and 'people' healthy development, this paper makes a beneficial exploration on the professional construction of domestic data science and big data. The next step is to refine each course according to the OBE philosophy, to support the graduation requirements with course objectives, and to achieve quantifiable professional training goals.

\section{ACKNOWLEDGMENT}

This work was supported by the Education Research and Reform Project of Chengdu University of Information Technology (JY2018054).

\section{REFERENCES}

[1] X. Q. Gong, C. Q. Jin, X. L. Wang, et al. Dataintensive science and engineering: requirementss and challenges, Chinese Journal of Computers, vol. 35, pp. 1563-1578, 2012.

[2] H. C. Ning. Study on interdisciplinary model of construction of big data discipline in china, Computer Science, vol. 46, pp. 159-162, 2019.

[3] Big data industry ecological union. 2019 China big data industry development white paper. http://www.bdinchina.com/Article/info/id/611.html,2019.

[4] Chinese Computer Federation. White paper on China's big data technology and industrial development, https://www.ccf.org.cn/wqxwcx/ccflwz/2013-12-20 /648192.shtml,2013.

[5] P. H. Gu. The Concept, Framework and implement approaches of emerging engineering education(3E) and the new paradigm, Research in Higher Education of Engineering, pp. 1-13, 2017.

[6] Y. L. Wang, M. Zhang, G. Q. You. A preliminary study on the construction of data science and big data technology under the background of new engineering education, Shanxi Education (Higher Education), pp. 4445,2020

[7] S. Liu, P. Chen, W. Wang, et al. Design of big data curriculum system in the nationalities universities with Engineering Education Certification, Computer Era, pp. 74-77, 2020.

[8] Z. Peng, Y. Dong, X. W. Wang. Research of the major of big data management and application of its curriculum system, China Modern Educational Equipment, pp. 49-51, 2020.

[9] S. T. Sun, L. G. Zhu, C. F. Li. Analysis of the course system of data science majors in well-known universities in north America, The Chinese Journal of ICT in Education, pp. 48-50, 2019. 